\title{
STATE OBLIGATIONS RELATED TO THE LAUNCH OF OBJECTS INTO OUTER SPACE UNDER INTERNATIONAL LAW
}

\author{
Riza Amalia \\ Faculty of Law, Universitas Lampung, Indonesia, Email: rizaa237@gmail.com
}

Submitted: June 25, 2020; Reviewed: July 21, 2020; Accepted: August 13, 2020

\begin{tabular}{|c|c|c|}
\hline Article Info & & Abstract \\
\hline $\begin{array}{l}\text { Keywords: } \\
\text { Registration, Space, } \\
\text { Obligations. }\end{array}$ & Object, & $\begin{array}{l}\text { Space utilization is currently experiencing a very rapid } \\
\text { increase. Many countries have carried out various missions } \\
\text { by launching space objects. In launching an object into } \\
\text { space, the state has several obligations that must be fulfilled, }\end{array}$ \\
\hline $\begin{array}{l}\text { DOI: } \\
\text { 10.25041/lajil.v2i2.2035 }\end{array}$ & & $\begin{array}{l}\text { at least according to the author there are three basic } \\
\text { obligations namely, registration, supervision, and } \\
\text { responsibility when a loss occurs. For this reason, this study } \\
\text { aims to provide information on how to carry out these } \\
\text { obligations under international law. The method used in this } \\
\text { study is the normative judicial approach. A normative } \\
\text { juridical approach is a legal research conducted by } \\
\text { examining library materials or secondary data as a basis for } \\
\text { research by conducting a search of regulations and literature } \\
\text { relating to the problem under study. The launch of space } \\
\text { objects certainly has a regulation that is used as a standard } \\
\text { worthy of launching space objects such as satellites. The } \\
\text { launch is regulated in the } 1976 \text { Registration Convention and } \\
\text { registered with an international institution, the International } \\
\text { Telecommunication Union (Article iv (1) 1976 registration } \\
\text { convention). In addition to registering space objects, the } \\
\text { state must also supervise these space objects to find out the } \\
\text { development of the mission they made (Article VI Outer } \\
\text { Spece Treaty 1967), and the last is the responsibility of a } \\
\text { country when a loss arises due to the space object. This is } \\
\text { regulated in the 1967 Outer Space Treaty (Article VII) and } \\
\text { the } 1972 \text { Liability Convention. }\end{array}$ \\
\hline
\end{tabular}

\section{A. Introduction}

Outer space began to be known since the launch of the first satellite, the Sputnik 1 satellite on October 4, 1957. Since then, outer space has become increasingly known and a place to launch other satellites, especially from the Superpowers at that time such as the United States and the Soviet Union. ${ }^{1}$ Originally the Sputnik 1 Satellite was sent as a means of a power struggle between the United States and the Soviet Union in the case of the first country to send its

\footnotetext{
${ }^{1}$ Huala Adolf, Aspek-aspek Negara dalam Hukum Internasional (Jakarta: Raja Grafindo Persada, 2002), 137.
} 
astronauts to the moon and also to assist in the use of outer space. ${ }^{2}$ In 1961 the Soviet Union succeeded in sending Yuri Gagarin with the help of the Vostok rocket as the first astronaut to succeed in outer space, and finally, the United States also succeeded as the first country to land on the moon with Apollo 11 in 1969. ${ }^{3}$

Very rapid technological developments, not only in the United States and the Soviet Union, who want to make use of outer space. Now almost all countries in the world have launched objects into outer space, with various missions and goals. Indonesia itself has launched 25 satellites starting in 1976 by launching Indonesia's first satellite, named Palapa A1. ${ }^{4}$ Launching objects into outer space such as satellites that have various purposes and functions, such as the Himawari satellite from the Japan Meteorological Agency which is used as a weather observer, which is used to monitor natural disasters and weather forecasts, climate change and the environment as well as short weather forecast capability (6 hours) including bad weather protection and predictions. ${ }^{5}$

Arrangements regarding the launch of objects into outer space are usually discussed in air and outer space law books which are part of the international law branch. Air law and outer space law have different arrangements, although they are often used as discussions in one book. Air law usually regulates aircraft, air navigation, and commercial air transportation, while outer space law regulates outer space activities such as launching space objects and orbital regions of space objects. Related to the discussion this time, the author will discuss outer space because it regulates the discussion of objects in outer space.

When a country launches an object into space, then that country has several obligations that must be fulfilled both when it will be launched, when it has been launched and when returning to earth. When a country launches celestial bodies such as satellites, registration aims to facilitate the identification of ownership of space objects, when causing harm to other countries, this is regulated in the $1998^{6}$ International Telecommunications Union Convention, then regarding the supervision that must be carried out by the state that owns the object when has been launched regulated in the 1967 space agreement. The last is the Space Agreement 1967 and the Liability Convention 1972, which regulates the state's responsibility to be responsible and provide compensation when space objects cause loss or damage to other parties and countries both in space, space air and land.

In the 1998 International Telecommunication Union Convention, ${ }^{7}$ when a country would register a space object, they also had to register the satellite orbit/space object. However, only a few states have developed the technology to launch and manufacture satellites. ${ }^{8}$ For writers

\footnotetext{
2 https://internasional.kompas.com/read/2018/10/04/17283941/kisah-sputnik-1-satelit-pertama-dunia-yangmeluncur-ke-angkasa, Accessed on June 10, 2020.

${ }^{3}$ Syahmin AK, dkk, Hukum Udara Dan Luar Angkasa (Air And Outer Space Law), (Palembang: Unsri Pers, 2012), 43.

4 https://www.cnbcindonesia.com/news/20190224152921-4-57317/inilah-25-satelit-milik-indonesia-dari-waktuke-waktu, Accessed on June 10, 2020.

5 Nanik Suryo Haryani, “POTENSI PEMANFAATAN DATA SATELIT HIMAWARI”, Berita Dirgantara 18, no. 2 (2017): 93-98, 93.

${ }^{6}$ Muh. Kadarisman, A. Syukri, Pendaftaran Orbit Satelit Oleh Negara Berdasarkan Konvensi International Telecomunication Union (ITU) 1998 (Makasar: Universitas Hasanudin, 2012), 49.

7 The Convention is an instrument usually used in multilateral agreements which regulates limited or open important matters, and usually not simple and detailed. Desia Rakhma Banjarani et al., "PERLINDUNGAN TERHADAP WARTAWAN PERANG DI DAERAH KONFLIK BERSENJATA MENURUT HUKUM INTERNASIONAL (STUDI KASUS DAERAH KONFLIK IRAK DAN SURIAH) PROTECTION OF WAR REPORTERS IN ARMED CONFLICT AREAS BASED ON INTERNATIONAL LAW (CASE STUDY OF THE IRAQ AND SYRIA CONFLICT)," Cepalo 3, no. 1 (2019): 11-18, 14, DOI: 10.25041/cepalo.v3no1.1789.

${ }^{8}$ Upasana Dasgupta, "Reconciling State Practice of in Orbit Satellite Tranfer With the Law of Liability and Registration in Outer Space", Centre For Research in Air And Space Law's Sixth Monograph, Global Space Governance and the UN 2030, 2018.
} 
for the launching country, it is important to know at least three of the obligations mentioned above, namely, registration, supervision and compensation to those injured due to the object being launched. Therefore, the authors are interested in discussing more how to fulfil the obligations of launching countries under international law. The method used in this study is a normative juridical approach. A normative juridical approach is an approach that is a scientific procedure for finding truth based on scientific logic from the normative side whose object is the law itself. ${ }^{9}$ According to Soerjono Soekanto, the normative juridical approach is legal research carried out by examining literature or secondary data as a basic material to be investigated by searching for regulations and literature relating to the problem under study. ${ }^{10}$

\section{B. Discussion}

This paper shows that in the use of space, several regulations must be obeyed by all countries, these regulations can be in the form of conventions, treaties, and other international agreements. The regulation regulates a number of different things, as the authors will discuss below. the International Telecommunication Union Convention 1998 regulates satellite registration, then the supervision that must be carried out by the state of its space object when it is launched it is regulated in the Outer Space Treaty 1967 and most recently the Outer Space Treaty 1967 and the Liability Convention 1972, which regulates obligations the state of being responsible and provide compensation when his space object causes loss or damage to other parties and countries both in space, air space and land. ${ }^{11}$

\section{Registration of Space Object}

When a country launches an object into space, the country must first register it with an international organization, the International Telecommunication Union, and report the registration to the Secretary-General of the United Nations. ${ }^{12}$ International Telecommunication Union or often abbreviated as ITU is an organization that allocates global radio spectrum and satellite orbits, develops technical standards that ensure networks and technologies seamlessly interconnect, and strive to improve access to ICTs to underserved communities worldwide. The benefits that we can feel from the existence of ITU, one of which is that we can make phone calls through cellphones and access the Internet or send the email. ${ }^{13}$ Registration of space objects is regulated in a convention called Registration Convention 1976. ${ }^{14}$ The Registration Convention is considered and negotiated by the Legal Subcommittee from 1962. This convention was adopted by the General Assembly in 1974 (General Assembly resolution 3235 (XXIX)), opened for signed on January 14, 1975, and entered into force on September 15, $1976 .{ }^{15}$ The launching countries must prepare several things before registering the object to be launched, namely: ${ }^{16}$

a) Name of launching State or States;

b) An appropriate designator of the space object or its registration number;

\footnotetext{
${ }^{9}$ Johny Ibrahim, Teori\&Metodologi Penelitian Hukum Normatif (Malang: Bayumedia, 2011), 57.

${ }^{10}$ Soerjono Soekanto \& Sri Mamudji, Penelitian Hukum Normatif (Suatu Tinjauan Singkat), (Jakarta: Rajawali Pers, 2001), 13-14.

${ }^{11}$ Alan S. Belward, "WHO LAUNCHED WHAT, WHEN AND WHY, TRENDS IN GLOBAL LAND-COVER OBSERVATION CAPACITY FROM CIVILIAN EARTH OBSERVATION SATELLITES”, ISPRS Journal of Photogrammetry and Remote Sensing 103, no. 120 (2015): 115-128, 115, DOI: 10.1016/j.isprsjprs.2014.03.009.

12 Article 2 Registrtion Convention 1976.

${ }^{13}$ https://www.itu.int/en/about/Pages/default.aspx, Accessed on June 10, 2020.

${ }^{14}$ Zhao Yun, "REVISITING THE 1975 REGISTRATION CONVENTION: TIME FOR REVISION?", Australian Journal of International Law 11, (2004): 106-127, 106.

15 https://www.unoosa.org/oosa/en/ourwork/spacelaw/treaties/introregistration-convention.html, Accessed on June 10, 2020.

${ }^{16}$ Article IV (1) Registration Convention 1976.
} 
c) Date and territory or location of launch;

d) Basic orbital parameters, including Nodal period, Inclination, Apogee,${ }^{17}$ Perigee $;{ }^{18}$

e) General function of the space object.

Launching State means: (i) A State which launches or procures the launching of a space object; (ii) A State from whose territory or facility a space object is launched ${ }^{19}$ so that the number of launcher states can be more than one. When registering a space object, they must choose one of the countries that will register the space object. In addition to registering space objects from the launching country, the country must also register a satellite orbit. This has been regulated based on the 1998 International Telecommunication Union convention. ${ }^{20}$ If we pay attention to the satellite registration requirements, it is natural that in launching a space object such as a satellite the number of launching countries is not just one, because of the large costs required to launch it. ${ }^{21}$ In Indonesia itself when an institution or prospective satellite provider is required to submit a request for satellite registration to the International Telecommunication Union (ITU) in writing to the Minister. In the application for registration must attach the following: ${ }^{22}$

a. Radiofrequency spectrum data used;

b. Coverage area;

c. Number of transponders;

d. Satellite age;

e. Information on the analysis of the selection of orbit locations and the system to be used;

f. Statement letter capable of carrying out satellite coordination;

g. Affidavit capable of following the satellite registration procedure;

h. Affidavit capable of covering the satellite registration fees set by itu; and

i. Declaration letter is able to fulfill all other requirements stipulated by itu.

After registering then ITU will conduct an evaluation, and will return the application file if any of the following occurs: ${ }^{23}$

a. There is a lack of requirements as determined by ITU or is not equipped with information or data needed; or

b. There is a clarification request in the form of additional information from ITU.

\section{Supervision of Space Object}

When a country has launched its object into space, the country is asked to supervise its outer space object. This is done to protect space objects, protect the rights of other countries and protect space objects belonging to other countries. The purpose of keeping his space objects is that with the supervision of these space objects, the state can anticipate when something unexpected happens. An example is when a space object collides with another space object, the country can manoeuvre or avoid the object, so that the collision can be avoided. Then is protecting the rights of other countries and protecting space objects belonging to other countries, this is intended when a country oversees space objects so that this will anticipate collisions with objects belonging to other countries that can cause harm. When the state

\footnotetext{
${ }^{17}$ Apogee is the furthest point from Earth in a satellite orbit.

${ }^{18}$ Perigee is the closest distance to the earth.

${ }^{19}$ Article I (a) Registration Convention 1976.

${ }^{20}$ Armel Kerrest, "Launching Spacecraft From The Sea And The Outer Space Treaty: The Sea Launch Project", Journal Air \& Space Law 23, no. 1 (1998): 16.

${ }^{21}$ Timo Wekerle, "STATUS AND TRENDS OF SMALLSATS AND THEIR LAUNCH VEHICLES- AN UP TO

DATE REVIEW”, Journal Aerosp Technol Manage 9, no. 3 (2017): 269-286, 269, DOI: 10.5028/jatm.v9i3.853.

22 Article 10 (2) Regulation of the Minister of Communication and Information Technology Number: 13/P/M.Kominfo/8/2005 concerning the Implementation of Telecommunications Using Satellite.

23 Article 12 (1) Regulation of the Minister of Communication and Information Technology Number: 13/P/M.Kominfo/8/2005 concerning the Implementation of Telecommunications Using Satellite.
} 
oversees a space object and manoeuvres when a collision will occur, this will minimize the cascade, so as to reduce the amount of space debris. Supervision of space objects is regulated in Article VI Outer Spece Treaty 1967, which reads:

"States Parties to the Treaty shall bear international responsibility for national activities in outer space, including the Moon and other celestial bodies, whether such activities are carried on by governmental agencies or by non-governmental entities, and for assuring that national activities are carried out in conformity with the provisions outlined in the present Treaty. The activities of non-governmental entities in outer space, including the Moon and other celestial bodies, shall require authorization and continuing supervision by the appropriate State Party to the Treaty. When activities are carried on in outer space, including the Moon and other celestial bodies, by an international organization, responsibility for compliance with this Treaty shall be borne both by the international organization and by the States Parties to the Treaty participating in such organization." 24

From this article, we can see that the state through governmental or non-governmental institutions still has an obligation to conduct surveillance to ensure that the objective of launching the space object is achieved.

\section{The Launcher's Country Responsibilities of Space Object}

The responsibility regarding space utilization activities is regulated in the Outer Space Treaty 1967, namely Article VII, but is only explained in general. International responsibility must be carried out by countries that carry out activities in space. As is well known that space activities can be carried out by the government and also the private sector, but in carrying out their activities, the private sector must obtain prior permission from the government of the member countries of the organization. Whereas international organizations must obtain permission from the organization and the government of the member countries of the organization. The essence of Article VII states that the launching country is responsible for all things arising from space activities, which are carried out by that country. ${ }^{25}$

Next is about compensation. The compensation resulting from this activity in space is listed in Article VIII of the Outer Space Treaty $1967 .{ }^{26}$ Compensation for losses caused by space objects such as satellites, the injured party can file a claim with the launching country. The launching country, in this case, is the country that launched the object into space, or it could also be the country that helped finance the launch and also the country where the celestial object was launched. There is also the principle of preventing pollution and contamination from space objects. This principle emphasizes that activities carried out in space and other celestial bodies must be maintained so that pollution and contamination do not occur. This is very necessary for environmental sustainability that can provide benefits for the continuity of activities in space and also for the benefit of humanity on earth, so if we apply these principles, it can reduce pollution and contamination in space. This principle is stated in Article IX of the Outer Space Treaty $1967 .{ }^{27}$

In addition to the outer space treaty, the state's responsibilities related to space activities will be more detailed in the Liability Convention 1972. Parties that can be held liable for losses caused by space objects are not only countries that launch these space objects, but all countries that have a role in launching the spacecraft can be held liable, both in terms of funding or the country where the aircraft was launched. This is in accordance with Article I Paragraph (c) of

\footnotetext{
${ }^{24}$ Article VI Outer Spece Treaty 1967.

${ }^{25}$ Siti Azizah, Hukum Angkasa Internasional, (Bandar Lampung: Pusaka Media, 2017), 15.

${ }^{26}$ Promit Chatterjee, "LEGALITY OF ANTI SATELLITES UNDER THE SPACE LAW REGIME", Journal Astropolitics 12, no. 1 (2014): 27-45, 27, DOI: 10.1080/14777622.2014.891558.

${ }^{27}$ Agus Pramono, Dasar-dasar Hukum Udara Dan Ruang Angkasa (Bogor: Penerbit Ghalia Indonesia, 2011$), 21$.
} 
the Liability Convention 1972. Then pay attention to the following Article II and III of the Liability Convention 1972:

"A launching State shall be absolutely liable to pay compensation for damage caused by its space object on the surface of the Earth or to aircraft flight." (Article II)

"In the event of damage being caused elsewhere than on the surface of the Earth to a space object of one launching State or to person s or property on board such a space object by a space of another launching State, the latter shall be liable only if the damage is due to its fault or the fault of persons for whom it is responsible." (Article III)

Based on the two articles above, this convention provides two alternatives in the responsibility of a country for losses caused by space objects, namely absolute liability and based on fault liability. Absolute responsibility is a responsibility where the element of error does not need to be proven by the plaintiff, as the basis for compensation payments. At the same time, the responsibility based on mistakes is any act that violates the law that causes harm to others, obliging people who because of their mistakes to compensate the injured party. Absolute responsibility is often known as strict liability or legal liability without fault concept; in Indonesian, it is referred to as the principle of direct and immediate responsibility. There are differences of opinion about the term. Some experts distinguish between absolute liability and strict liability. ${ }^{28}$

In strict liability, there is still the possibility of exclusion of liability, i.e. if the damage or accident is caused by natural disasters, warfare, coercive circumstances or third party actions. Whereas in absolute responsibility, the exclusion system no longer applies, so the defendant is obliged to carry out this responsibility without reason. So if the writer concludes, what is used in the Liability Convention 1972 is absolute responsibility, not strict responsibility. Article II states that the launching country has an absolute responsibility, to pay compensation for losses suffered by a country due to activities carried out by the country in space, but the loss is on earth or on an aircraft that is operating. The purpose of Article II is that if there is a loss on earth or on an operating aircraft caused by space objects, the responsibility used is absolute responsibility. So that if there is damage on the surface of the earth caused by space objects, contamination of an ecosystem due to nuclear fuel from space objects causing loss or even loss of life, or aircraft that are crossing and being hit by satellites that are being launched into space. If this happens, the satellite launch country has an obligation to carry out absolute responsibility for the losses incurred. ${ }^{29}$

The existence of the principle of absolute liability in space activities is caused by the inability of the injured party to provide detailed proof as is usually done when there is a general compensation case that requires proof elements such as intentional errors and omissions. ${ }^{30}$ But in space activities, the plaintiff's claim can be easily rejected due to technical difficulties that are only known and understood by the launching party, so it is tough to prove. Whereas Article III explains that if the damage or loss suffered by a country is in space, for example, such as a collision between satellites, the responsibility used is responsibility based on fault liability so that a launching country can be found guilty if the plaintiff's country can prove the fault of the launching state. In addition to absolute liability and based on fault liability, in space activities

28 Joel A Dennerley, "STATE LIABILITY FOR SPACE OBJECT COLLISIONS: THE PROPER INTERPRETATION OF 'FAULT' FOR THE PURPOSES OF INTERNATIONAL SPACE LAW", European Journal of International Law 29, no. 1 (2018): 281-301, 281, DOI: 10.1093/ejil/chy003.

${ }^{29}$ J. A. Burke, "CONVENTION ON INTERNATIONAL LIABILITY FOR DAMAGE CAUSED BY SPACE OBJECTS: DEFINITION AND DETERMINATION OF DAMAGES AFTER THE COSMOS 954 INCIDENT", Fordham International Law 8, no. 2 (1984): 255-285, 255.

${ }^{30}$ Ram S. Jakhu, "REGULATORY FRAMEWORK AND ORGANIZATION FOR SPACE DEBRIS REMOVAL AND ON ORBIR SERVICING OF SATELLITES”, Journal of Space Safety Engineering 4, no. 4 (2017): 129137, 129, DOI: 10.1016/j.jsse.2017.10.002. 
also known as jointly and severally liable, which is a responsibility where launching countries are jointly responsible for damage caused by the space object they launch. ${ }^{31}$

The Liability Convention 1972 also regulates how to make compensation, which is regulated in Article IX. A claim for compensation submitted by the claimant state to the launching country is carried out through diplomatic channels. This is done because the diplomatic channel is considered to be able to prevent one party from feeling aggrieved or burdensome. After all, the purpose of the settlement by using the diplomatic channel is to prevent conflict. Meanwhile, if the country experiencing loss or claimant state does not have diplomatic relations with the launching country, the claimant country may request assistance from other countries that have diplomatic relations with the launching country. Alternatively, you can also submit a claim through the UN Secretary-General, if the defendant and the plaintiff are both United Nations member states. ${ }^{32}$

The claim must be submitted to the launching country for no more than one year. Starting from the date of the loss or can also be calculated from knowing which countries are responsible. Compensation to be paid must be in accordance with the currency of the injured country, or another country's currency in accordance with the agreement. The following is the sound of Article IX:

"A claim for compensation for damage shall be presented to a launching State through diplomatic channels. If a State does not maintain diplomatic relations with the launching State concerned, it may request another State to present its claim to that launching State or otherwise represent its interests under this convention. It may also present its claim through the SecretaryGeneral of the United Nations, provided the claimant State and the launching State are both members of the United Nations."

In addition, there is also a way to settle the compensation contained in Article XII, namely that the compensation that must be paid by the launching country must be in accordance with the principle of justice and equality. The principle of justice can be interpreted as a moral obligation to act on the basis of a fair decision on an issue. At the same time, the principle of equality is the same treatment or the same position between the parties in conflict. That is, the launching state does not feel burdened by the claimant state because of its mistakes by overestimating its claims which are not in accordance with the losses suffered by the claiming state. The following is the sound of the contents of Article XII Liability Convention 1972:

"The compensation which the launching State shall be liable to pay for damage under this Convention shall be determined in accordance with international law and the principles of justice and equity, in order to provide such reparation in respect of the damage as will restore the person, natural or juridical, State or international organization on whose behalf the claim is presented to the condition which would have existed if the damage had not occurred."(Article XII)

Based on these articles, it can be seen that in the Liability Convention 1972 prioritizes the principle of equality or anti-discrimination, this can be seen from the implementation of the principles of justice and equality when a country resolves a compensation case. In addition, the Liability Convention 1972 also facilitated the settlement of compensation. This can be seen from the way the prosecution of compensation can be through many ways, namely through diplomatic channels, third parties or parties who have diplomatic relations with the two countries in dispute, and through the Secretary General of the United Nations if the two countries in dispute it is a member of the United Nations.

\footnotetext{
${ }^{31}$ Ibid.

${ }^{32}$ U. S. Silwanus, "TANGGUNG JAWAB NEGARA PELUNCUR BENDA ANGKASA TERKAIT MASALAH LUAR ANGKASA (SPACE DEBRIS) BERDASARKAN LIABILITY CONVENTION 1972", JOM:Fakultas Hukum 3, no. 2 (2016): 1-15, 1.
} 


\section{Conclusion}

In fulfilling three essential obligations that must be fulfilled by a country when launching a celestial body, there are at least three things, namely registration, supervision, and responsibility when a loss occurs. Launching space objects certainly has a regulation that is used as a standard worthy of launching space objects such as satellites. The launch is regulated in the Registration Convention 1976 and registered with an International Institution, The International Telecommunication Union (Article Iv (1) Registration Convention 1976), the state must prepare an application attachment to register it and ITU and return it if the application does not meet the requirements. In addition to registering space objects, the state must also supervise these space objects to find out the development of the mission they made (Article VI Outer Spece Treaty 1967), and the last is the responsibility of a country when a loss arises due to the space object. This is regulated in the 1967 Outer Space Treaty (Article VII) and the 1972 Liability Convention.

\section{A. Journal}

\section{References}

Banjarani, Desia Rakhma, et al. "PERLINDUNGAN TERHADAP WARTAWAN PERANG DI DAERAH KONFLIK BERSENJATA MENURUT HUKUM INTERNASIONAL (STUDI KASUS DAERAH KONFLIK IRAK DAN SURIAH) PROTECTION OF WAR REPORTERS IN ARMED CONFLICT AREAS BASED ON INTERNATIONAL LAW (CASE STUDY OF THE IRAQ AND SYRIA CONFLICT)," Cepalo 3, no. 1, 2019: 11-18, DOI: 10.25041/cepalo.v3no1.1789.

Belward, Alan S. "WHO LAUNCHED WHAT, WHEN AND WHY, TRENDS IN GLOBAL LAND-COVER OBSERVATION CAPACITY FROM CIVILIAN EARTH OBSERVATION SATELLITES", ISPRS Journal of Photogrammetry and Remote Sensing 103, no. 120, 2015: 115-128, DOI: 10.1016/j.isprsjprs.2014.03.009

Burke, J. A. "CONVENTION ON INTERNATIONAL LIABILITY FOR DAMAGE CAUSED BY SPACE OBJECTS: DEFINITION AND DETERMINATION OF DAMAGES AFTER THE COSMOS 954 INCIDENT", Fordham International Law 8, no. 2, 1984: 255-285.

Chatterjee, Promit. "LEGALITY OF ANTI SATELLITES UNDER THE SPACE LAW REGIME", Journal Astropolitics 12, no. 1, 2014: 27-45, DOI: 10.1080/14777622.2014.891558.

Dasgupta, Upasana. "RECONCILING STATE PRACTICE OF IN ORBIT SATELLITE TRANFER WITH THE LAW OF LIABILITY AND REGISTRATION IN OUTER SPACE", Centre For Research In Air And Space Law's Sixth Monograph, Global Space Governance and The UN 2030, 2018.

Dennerley, Joel A. "STATE LIABILITY FOR SPACE OBJECT COLLISIONS: THE PROPER INTERPRETATION OF 'FAULT' FOR THE PURPOSES OF INTERNATIONAL SPACE LAW", European Journal of International Law 29, no. 1, 2018: 281-301, DOI: 10.1093/ejil/chy003.

Haryani, Nanik Suryo. "POTENSI PEMANFAATAN DATA SATELIT HIMAWARI”, Berita Dirgantara 18, no. 2, 2017: 93-98.

Jakhu, Ram S. "REGULATORY FRAMEWORK AND ORGANIZATION FOR SPACE DEBRIS REMOVAL AND ON ORBIR SERVICING OF SATELLITES", Journal of Space Safety Engineering 4, no. 4, 2017: 129-137, DOI: 10.1016/j.jsse.2017.10.002.

Kerrest, Armel. "LAUNCHING SPACECRAFT FROM THE SEA AND THE OUTER SPACE TREATY: THE SEA LAUNCH PROJECT", Journal Air \& Space Law 23, no. 1, 1998: 16. 
Silwanus, U. S. "TANGGUNG JAWAB NEGARA PELUNCUR BENDA ANGKASA TERKAIT MASALAH LUAR ANGKASA (SPACE DEBRIS) BERDASARKAN LIABILITY CONVENTION 1972”, JOM:Fakultas Hukum 3, no. 2, 2016: 1-15.

Wekerle, Timo. "STATUS AND TRENDS OF SMALLSATS AND THEIR LAUNCH VEHICLES- AN UP TO DATE REVIEW", Journal Aerosp Technol Manage 9, no. 3, 2017: 269-286, DOI: 10.5028/jatm.v9i3.853.

Yun, Zhao. "REVISITING THE 1975 REGISTRATION CONVENTION: TIME FOR REVISION?”, Australian Journal of International Law 11, 2004: 106-127.

\section{B. Book}

Adolf, Huala. Aspek-aspek Negara dalam Hukum Internasional, Jakarta: Raja Grafindo Persada, 2002.

AK, Syahmin. Hukum Udara Dan Luar Angkasa (Air And Outer Space Law). Palembang: Unsri Pers, 2012.

Azizah, Siti. Hukum Angkasa Internasional, Bandar Lampung: Pusaka Media, 2017.

Ibrahim, Johny. Teori\&Metodologi Penelitian Hukum Normatif. Malang: Bayumedia, 2011.

Kadarisman, A., \& Syukri, Muh. Pendaftaran Orbit Satelit Oleh Negara Berdasarkan Konvensi International Telecomunication Union (ITU) 1998. Makasar: Universitas Hasanudin, 2012.

Pramono, Agus. Dasar-Dasar Hukum Udara Dan Ruang Angkasa. Bogor: Penerbit Ghalia Indonesia, 2011.

Soekanto, Soerjono., \& Mamudji, Sri. Penelitian Hukum Normatif (Suatu Tinjauan Singkat). Jakarta: Rajawali Pers, 2001.

\section{Regulation}

Liability Convention 1972.

Outer Space Treaty 1967.

Registration Convention 1976.

Regulation of the Minister of Communication and Information Technology Number: 13/P/M.Kominfo/8/2005 concerning the Implementation of Telecommunications Using Satellite.

\section{Internet}

https://www.cnbcindonesia.com/news/20190224152921-4-57317/inilah-25-satelit-milikindonesia-dari-waktu-ke-waktu, Accessed on June 10, 2020.

https://www.itu.int/en/about/Pages/default.aspx, Accessed on June 10, 2020. 
